\title{
SYURA DAN DEMOKRASI BARAT: KRITIK DAN SOLUSI MENUJU DEMOKRASI ISLAM
}

\author{
Toha Andiko \\ Program Studi Hukum Islam Pascasarjana IAIN Bengkulu \\ Jl. Raden Fatah Pagar Dewa Bengkulu \\ Email: toha.andiko@gmail.com
}

\begin{abstract}
Western scholars require democracy to meet the elements of tolerance, consultation, elections, balance, evaluation, separation of powers and political participation. However, in practice democracy is often equated with the experience and political traditions of Western Europe and the United States. Western countries often adopt a double standard in the conduct of democracy, this is evident from their democratic attitudes while in the country, and not democratic outside of the country. Another example of the multiparty and parliamentary electoral systems that prevail in Britain and France is not universally accepted as a single model of democracy. The Islamic democracy sometimes identified with shura is not an end in itself, but a way to arrive at the noblest goal of applying the Islamic Shari'ah. The Islamic government is a mixture of presidential and parliamentary systems. It has four organs: the presidential institution, the ahl al-Hall wa al-'Aqd council, the shura council, and the judiciary. The first three institutions are the selected institutions, therefore are directly accountable to the people. Members of judicial institutions are appointed by the President, but the President has no constitutional right to intervene in their work. The judiciary is immune from any influence, unless its decision is against the Shari'a. Thus, shura is the backbone of the Islamic political system, as the process by which it is produced and generated decisions on binding public affairs.
\end{abstract}

Keywords: syura, Western democracy, Islamic democracy

\begin{abstract}
Abstrak: Cendikiawan Barat mensyaratkan demokrasi harus memenuhi unsur toleransi, konsultasi, pemilihan umum, keseimbangan, evaluasi, pemisahan kekuasaan dan partisipasi politik. Namun, dalam prakteknya demokrasi sering disamakan dengan pengalaman dan tradisi politik Eropa Barat dan Amerika Serikat. Negara Barat tak jarang menerapkan standar ganda dalam menjalankan demokrasi, ini tampak dari sikap demokratis mereka saat di negaranya, dan tidak demokratis di luar negaranya. Contoh lainnya sistem pemilihan umum multi partai dan parlemen yang berlaku di Inggris dan Prancis, tidak bisa diterima secara universal sebagai model tunggal demokrasi. Demokrasi Islam yang terkadang diidentikkan dengan syura bukanlah sebagai tujuan, melainkan suatu cara untuk sampai kepada tujuan paling mulia, yaitu penerapan syariat Islam. Pemerintahan Islam merupakan campuran antara sistem presidensiil dan parlementer. Ia memiliki empat organ: institusi kepresidenan, dewan ahl al-Hall wa al-Aqqd, dewan syura, dan institusi peradilan. Tiga institusi pertama adalah lembaga-lembaga yang dipilih, karena itu bertanggung jawab langsung kepada rakyat. Anggota institusi peradilan diangkat oleh Presiden, tetapi Presiden tidak memiliki hak konstitusional untuk intervensi dalam pekerjaan mereka. Lembaga peradilan adalah kebal dari pengaruh manapun, kecuali jika keputusannya bertentangan dengan syariat. Dengan demikian, syura merupakan tulang punggung sistem politik Islam, sebagai proses yang dengannya dibuat dan dihasilkan keputusan mengenai urusan publik yang bersifat mengikat.
\end{abstract}

Kata kunci: syura, demokrasi Barat, demokrasi Islam 


\section{Pendahuluan}

Perdebatan tentang Islam dan demokrasi tampaknya kini telah mulai memperoleh tempat yang signifikan dalam pemikiran politik Islam modern. Dalam upaya untuk menemukan suatu basis ideologis yang diterima oleh semua kalangan di dunia Islam, para pemikir dari kalangan Islam maupun sekuler dari masyarakat masyarakat muslim mulai merambah misi baru untuk merekonsiliasi perbedaan-perbedaan antara berbagai kelompok politik.

Harus diakui, bahwa salah satu hambatan terbesar yang dihadapi demokrasi pada saat ini umumnya terletak di dunia Islam. Hanya sedikit dari negara-negara Muslim yang telah membuat kemajuan menuju pembangunan sistem demokrasi. Di antara yang sedikit itu ialah Albania, Bangladesh, Yordania, Kyrgystan, Lebanon, Mali, Pakistan, dan Turki. Namun demikian, tidak satupun yang telah mencapai demokrasi secara penuh, stabil dan aman. Dan sebagian besar bertahan menghadapi pengaruh global menuju keragaman politik meliputi negaranegara Muslim di Timur Tengah dan Afrika Utara.

Kendati demikian, perlawanan terhadap perubahan politik di negara-negara Islam tidak selalu merupakan refleksi dari keimanan kaum Muslim. Banyak bukti justru menunjukkan sebaliknya. Perlawanan tersebut lebih banyak disebabkan oleh penguasa negara yang menolak berbagi kekuasaan, sehingga sangat anti demokrasi seperti di Arab Saudi, Brunei, Oman, Mesir, Qatar, Suriah, dan Turmenistan.

\section{Pengertian dan Sejarah Singkat Demokrasi}

Pemahaman hakekat demokrasi haruslah terlebih dahulu diawali dengan pengertian demokrasi serta nilai yang terkandung di dalamnya. Secara etimologis, demokrasi terdiri dari dua kata yang berasal dari bahasa Yunani, yaitu "demos" yang berarti rakyat atau penduduk suatu tempat dan "cratein" atau "cratos” yang berarti kekuasaan atau kedaulatan. Jadi "demos-cratein" atau "demos-cratos" (demokrasi) adalah kekuasaan atau kedaulatan rakyat, kekuasaan tertinggi berada dalam keputusan rakyat, rakyat berkuasa, pemerintahan rakyat dan kekuasaan oleh rakyat. ${ }^{1}$

Sementara itu, secara terminologis demokrasi mempunyai beberapa pengertian sebagai berikut: ${ }^{2}$

a) Menurut Joseft A. Schmeter, demokrasi merupakan suatu perencanaan institusional untuk mencapai keputusan politik dimana individu-individu memperoleh kekuasaan untuk meutuskan dengan cara perjuangan kompetitif atas suara rakyat; b) Menurut Sydney Hook, demokrasi adalah bentuk pemerintahan dimana keputusan-keputusan pemerintah yang penting secara langsung atau tidak langsung didasarkan pada kesepakatan mayoritas yang diberikan secara bebas dai rakyat biasa; c) Menurut Philippe C. Schimeter dan Terry Linn Karl, demokrasi merupakan suatu sistem pemerintahan dimana pemerintah dimintai tanggung jawab atas tindakan-tindakan mereka di wilayah publik oleh warga negara yang bertindak secara tidak langsung melalui kompetisi dan kerjasama dengan para wakil mereka yang telah terpilih.

Demokrasi sebagai dasar hidup bernegara mengandung pengertian bahwa pada tingkat terakhir rakyat memberikan ketentuan dalam masalah-maslah mengenai kehidupannya, termasuk dalam menilai kebijakan negara karena kebijakan tersebut menentukan kehidupan rakyat. Dari sudut organisasi, "demokrasi” berarti pengorganisasian negara yang dilakukan oleh rakyat sendiri atau atas persetujuan rakyat karena kedaulatan berada di tangan rakyat. ${ }^{3}$ Pendapat lain seperti seperti dinyatakan oleh Henry B. Mayo, bahwa demokrasi merupakan sistem politik yang menunjukkan bahawa kebijakan umum ditentukan atas dasar mayoritas oleh wakil-wakil yang diawasi secara efektif oleh rakyat dalam pemilihan-pemilihan berkala yang didasarkan atas prinsip persamaan politik dan diselenggarakan dalam suasana

1 Miriam Budiardjo, Demokrasi di Indonesia: Demokrasi Parlementer dan Demokrasi Pancasila, (Jakarta: Gramedia, 1996), h. 50

${ }_{2}^{2}$ Masykuri Abdillah, Demokrasi di Persimpangan Makna: Respon Intelektual Muslim Indonesia Terhadap Konsep Demokrasi (1966-1993), (Yogyakarta: Tiara Wacana, 1999), h. 73-73

${ }^{3}$ Moh. Mahfud MD, Hukum dan Pilar-Pilar Demokrasi, (Yogyakarta: Gema Media, 1999), h. 8. 
terjaminnya kebebasan politik. ${ }^{4}$

Dari beberapa pendapat di atas, terdapat benang merah atau titik singgung tentang pengertian demokrasi yaitu rakyat sebagai pemegang kekuasaan, pembuat dan penentu keputusan dan kebijakan tertinggi dalam penyelengaraan negara dan pemerintahan serta pengontrol terhadap pelaksanaan kebijakannya baik yang dilakukan secara langsung oleh rakyat atau mewakilinya melalui lembaga perwakilan. Karena itu, negara yang menganut sistem demokrasi diselenggarakan berdasarkan kehendak dan kemauan rakyat mayoritas dan juga tidak mengesampingkan kaum minoritas. Kekuasaan pemerintahan berada di tangan rakyat yang mengandung pengertian tiga hal penting. Pertama, pemerintah dari rakyat (government of the people); kedua, pemerintahan oleh rakyat (government by people); ketiga pemerintahan untuk rakyat (government for people). ${ }^{5}$

Para analis Barat telah meletakkan beberapa kriteria sebagai dasar bagi demokrasi, termasuk tingkat partisipasi politik, pemilu, partai-partai politik, kepentingan kelompok, pemisahan kekuasaan, checks dan balances, penghargaan terhadap HAM, hak-hak minoritas, dan kebebasan pers.

Kosa kata politik Islam itu sendiri sebenarnya tidak mengenal istilah demokrasi, karena istilah ini diperkenalkan oleh Hedorotus sekitar 3000 tahun yang lalu di Mesir kuno yang kemudian dikembangkan oleh kalangan pemikir Yunani kuno pada masa klasik. Istilah 'demokratia' yang diperkenalkan pada masa klasik di Yunani kuno adalah identik dengan institusi pengambil keputusan yang bersifat korektif yang terdiri dari para demos atau rakyat yang ada dalam polis. Dalam pemikiran masyarakat Yunani kuno, sebuah masyarakat yang demokratik haruslah paling tidak mencapai enam hal, yaitu 1) adanya keharmonisan dari kepentingan masyarakat polis 2)masyarakat polis haruslah bersifat homogen yang berkaitan dengan karakter mereka, jika tidak maka akan

\footnotetext{
${ }^{4}$ Moh. Mahfud MD, Hukum dan..., h. 9.

${ }^{5}$ Moh. Mahfud MD, Hukum dan..., h. 9.
}

menimbulkan konflik yang sangat tajam di antara mereka, 3) masyarakatnya tentu tidak saja terlampau besar untuk menghindari diri dari heterogenitas kepentingan. 4) warga masyarakat punya kebebasan untuk berkumpul dan memutuskan hukum dan kebijakan bersama 5) partisipasi masyarakat tidak dibatasi baik dalam pembuatan keputusan maupun dalam administrasi pemerintahan, dan yang terakhir adalah 6) polis tersebut haruslah bersifat otonom. ${ }^{6}$

\section{Prasyarat Demokrasi}

Lipset telah membuat hipotesa bahwa semakin baik yang dilakukan sebuah bangsa, semakin besar kesempatan untuk menjaga kelangsungan demokrasi, dan ini sangat berpengaruh dalam penjelasan kontemporer tentang demokrasi. ${ }^{7}$ Ia juga menekankan pentingnya pendidikan sebagai sebuah kondisi yang diperlukan untuk penegakan demokrasi. Beberapa sarjana lain telah menegaskan bahwa struktur sosial dan politik tertentu harus dibangun sebelum demokrasi bisa terwujud. Misalnya, dalam studi terakhirnya, Dahl menjelaskan bahwa lambannya laju demokratisasi lebih disebabkan oleh ketidaksamaan yang ekstrim dalam pembagian nilai-nilai kunci seperti pendapatan, kekayaan, status, pengetahuan dan kecakapan militer sampai pada ketidaksamaan yang ekstrim dalam sumber-sumber politik. ${ }^{8}$

Ketidaksamaan ekonomi di dalam negara adalah sangat penting karena mempengaruhi pembagian sumber-sumber kekuasaan. ${ }^{9}$ Implikasi dari pemusatan kekayaan di tangan para tuan tanah, keluarga berpengaruh dan elit politik akan berimplikasi bahwa populasi secara keseluruhan akan tercerabut dari kebutuhan dasar hidup, seperti perawatan kesehatan yang memadai, pendidikan dan tempat tinggal. Tingkat pembangunan sosial ekonomi berkaitan dengan munculnya berbagai

\footnotetext{
${ }^{6}$ Robert Dahl, Modern Political Analysist, (EnglewoodCliffs, NJ: Prentice Hall, 1976), edisi ketiga., h. 18-19.

7 Martin Seymour Lipset, Political Man: The Social Bases of Politics, (Doubleday, 1959), h. 75.

${ }^{8}$ Robert Dahl, Polyarchy, Participation and Opposition, (New Haven, Conn: Yale University Press, 1971), h. 3.

${ }^{9}$ Edward N. Muller, A Dependent Economic Development, Aid Dependence on the United States and Democratic Breakdown in the Third World, (International Studies, 1985), h. 445.
} 
kelompok dan asosiasi yang didefenisikan sebagai tumbuhnya civil society. Munculnya civil society dan demokrasi tidaklah memungkinkan dalam situasi yang rakyatnya harus terus-menerus khawatir akan kebutuhan dasar hidupnya. Tatu Vanhanen menegaskan,"pembagian relatif sumber-sumber ekonomi, intelektual dan sumber lainnya di kalangan berbagai segmen populasi merupakan faktor fundamental yang mesti diperhitungkan untuk variasi sistem politik dari aspek demokratisasi." ${ }^{10}$

\section{Unsur-Unsur Demokrasi Toleransi}

Jika toleransi dianggap sebagai pengamalan suatu prinsip dan ajaran kebenaran, maka kita tidak boleh memahaminya seperti di Eropa pada abad-abad yang lalu. Toleransi bukanlah sejenis netralisme kosong, yang bersifat proseduril semata, tapi suatu pandangan hidup yang berakar dalam kebenaran ajaran agama. Maka menghadapi millenium ketiga ini adalah saatnya para pemeluk semua agama ditantang untuk dapat dengan konkret menggali ajaran-ajaran agamanya dan mengembangkan paham toleransi yang otentik dan absah, sehingga toleransi bukan semata-mata persolanan prosedur pergaulan, tapi persoalan prinsip ajaran kebenaran.

Karena berbagai pengalaman sejarah, masyarakat Barat sendiri akhirnya mengakui bahwa toleransi adalah "prinsip yang akan memberi kesempatan terbaik kepada keimanan yang benar untuk menang: (Toleration is the principle which gives to the true faith the best chance of prevailing). ${ }^{11}$ Dan prinsip tidak dibenarkannya paksaan dalam agama yang ditegaskan dalam kitab suci Alquran pun berdasarkan pandangan bahwa yang benar jelas berbeda dari yang palsu, sehingga manusia dapat memilih sendiri dengan bebas dan tanggung jawab (QS. 2: 256). Maka ketika Rasulullah saw dalam Piagam Madinah meletakkan asas-asas pluralisme dan toleransi, dengan sendirinya beliau sama sekali tidaklah bertindak atas dasar kepentingan sesaat dan kegunaan jangka pendek, tapi karena

${ }^{10}$ Tatu Vanhanen, The Process Democratization; A Comparative Study of 147 States, (New York: Crane Russak, 1990), h. 47-51.

${ }^{11}$ John Herman Randall, Jr., The Making of The Modern Mind, (New York: Columbia University Press, 1976), h. 375 ajaran prinsipil dalam agama yang diwahyukan kepada beliau. Dengan demikian, masyarakat madani mewujudkan "keadaban politik" (political civility), yaitu pandangan dan sikap sosial politik yang beradab karena perbedaan pandangan dalam masyarakat tidak serta merta dipandang dengan rasa permusuhan, dan karena senantiasa terdapat kesediaan untuk menyelesaikan perbedaan itu melalui musyawarah secara damai, penuh pengertian satu sama lain. ${ }^{12}$

\section{Musyawarah}

Konsep syura seringkali disalahpahami dalam literatur Barat. Arti syura dipahami sebagai konsultasi. Syura merupakan proses legislatif dengan badan eksekutif harus menerima keputusan badan legislatif. Ini adalah ketentuan Ilahi, sebab Allah telah memerintahkan Rasulullah saw untuk tidak membuat keputusan kecuali melalui syura. Oleh sebab itu, syura merupakan proses integral dalam berfungsinya negara Islam, karena ia satu-satunya cara kolektif yang benar yang dengannya umat atau para wakilnya bisa membuat dan mensahkan undang-undang atau keputusan yang sesuai dengan kepentingan nasional suatu bangsa. Dengan demikian, syura merupakan tulang punggung sistem politik Islam. Syura didefinisikan sebagai proses yang melaluinya dibuat dan dihasilkan keputusan mengenai urusan publik negara. Keputusan seperti itu mengikat pada badan eksekutif, karena syura adalah ketentuan Ilahi.

Para sarjana muslim kontemporer menyatakan perlunya institusionalisasi syura melalui pengangkatan dewan perwakilan atau parlemen. Perekrutan anggota dewan bersifat terbuka, dan parameter-parameternya yang diambil dari negaranegara demokratis libeal adalah adaptable terhadap sistem Islam. Satu-satunya perbedaan dalam peranan yang dimainkan oleh badan legislatif, baik dalam sistem politik Islam maupun sistem demokrasi global adalah di sekitar ruang lingkup legislasi. Dalam sistem politik Islam, ruang lingkup legislasi itu dibatasi oleh kaedah-kaedah "tidak

${ }^{12}$ Bernard Lewis, et. al., Islam, Liberalisme, Demokrasi, (Jakarta: Paramadina, 2002), h. 290. 
melarang kemashlahatan dan tidak mendatangkan kemudharatan”.13

\section{Pemilu}

Ummah (masyarakat) adalah satu-satunya pihak yang memiliki hak pilih. Pemilu yang bebas untuk memilih imam (Presiden) adalah prasyarat agar bai'ah (kontrak) itu sah. ${ }^{14}$ Negara Islam didasarkan atas prinsip tidak ada monopoli kekuasaan dan satusatunya cara untuk mewujudkan tujuan tersebut adalah melalui pemilu. Alquran mendeskripsikan kaum muslim dengan menyatakan: "Dan kepemimpinan di kalangan mereka dilakukan secara musyawarah” (QS.42:28).

Allah Swt memerintahkan Rasul-Nya untuk "Maafkanlah mereka, dan mohonkanlah ampun bagi mereka serta bermusyawarahlah dengan mereka dalam urusan negara (QS.3: 59). Dalam ayat lain Allah memerintahkan Rasul-Nya "untuk menyerahkan amanah kepada ahlinya” (QS.4: 59).

Pemikir-pemikir Islam seperti Ibnu Taimiyah, Ibnu Khaldun, Abu Hamid al-Ghazali, al-Mawardi dan lainnya sepakat tentang prinsip bahwa imam atau khalifah harus dipilih oleh rakyat. Ibnu Taimiyah membedakan khalifah dari raja dalam hal suksesi kekuasaan, yang pertama dipilih dan yang kedua diangkat secara paksa. Al-Nasafi menulis dalam bukunya "al-Aqaid” bahwa kaum muslim tidak memiliki pilihan lain kecuali memilih imam yang akan melaksanakan hukum-hukum Islam, mewujudkan keadilan, mendistribusikan income nasional, mengasuh dan memperhatikan orangorang jompo serta terlibat dalam jihad. ${ }^{15}$

Para pemikir muslim kontemporer seperti Maududi, Muhammad al-Ghazali, Sa'id Hawwa dan para pemimpin gerakan Islam menekankan pentingnya pemilu dalam proses politik di negara Islam. Presiden dan para pembantunya harus dipilih oleh rakyat. ${ }^{16}$ Hasan al-Banna, pendiri Ikhwan al-Muslimun di Mesir, menuntut pemilihan

\footnotetext{
${ }^{13}$ Bernard Lewis, Islam, Liberalisme, Demokrasi, h. 184.

${ }^{14}$ Fahmi Huwaidi, “al-Islam wa al-Dimuqratiyah”, al-Mustaqbal al-'Arabi, no. 166, Desember 1992. 1993, h. 12-13

${ }^{15}$ Bernard Lewis, Islam, Liberalisme, Demokrasi, h. 185.

${ }^{16}$ Muhammad al-Ghazali, Huquq al-Insan ibn Ta'alim al-Islam wa Mitsaq al-Umam al-Muttahidah, (Kairo: Dar al-Kitab al-Hadits,1965), h. 80.
}

anggota parlemen yang bebas pada 1940-an. Dan banyak kalangan lain yang menyatakan keharusan pemilihan lembaga-lembaga negara secara bebas sehingga berimplikasi pada penerapan konsultasi dalam menjalankan roda pemerintahan. ${ }^{17}$

\section{Checks and Balances}

Selain itu, mempertimbangkan checks and balances tentu akan membantu dalam mengevaluasi proses demokrasi pada setiap negara. Pemerintahan Islam merupakan campuran antara sistem presidensiil dan parlementer. Ia memiliki empat organ: institusi kepresidenan, dewan ahl alHall wa al-AAqd, dewan syura, dan institusi peradilan. Tiga institusi pertama adalah lembaga-lembaga yang dipilih dan karenanya bertanggung jawb langsung kepada rakyat. Anggota institusi peradilan diangkat oleh Presiden, tetapi Presiden tidak memiliki hak konstitusional untuk intervensi dalam pekerjaan mereka. Lembaga peradilan adalah kebal dari pengaruh manapun, kecuali apabila keputusannya bertentangan dengan syari'at. Contoh lain dari independensi lembaga peradilan adalah ia dapat memanggil Presiden untuk menghadapi berbagai tuntutan yang dialamatkan kepadanya.

Pemisahan kekuasaan membentuk suatu prinsip lain yang menjadi basis bangunan pemerintahan Islam. Kekuasaan eksekutif dikepalai oleh Presiden. Ia bertanggung jawab kepada lembaga legislatif tertinggi yang disebut ahl al-Hall wa al'Aqd. Dewan ini memainkan peranan pengawasan (role of watch-dog) dan terdiri dari kelompok netral dan independen dengan latar belakang agama. Dewan inilah yang menafsirkan pasal-pasal dan klausulklausul konstitusi, me-review keputusan-keputusan yang telah diambil baik oleh dewan syura maupun Presiden, menyelesaikan segala bentuk pertentangan konstitusional antara badan legislatif dan badan eksekutif. $^{18}$

Kekuasaan-kekuasaan Presiden dibatasi oleh fakta bahwa ia diwajibkan untuk berkonsultasi kepada dewan syura dan terikat dengan keputusannya. ${ }^{19}$

17 Al-Maududi, Al-Hukumah al-Islamiyah, (Kairo: al-Mukhtar al-Islami, 1976), h. 138.

${ }^{18}$ Al-Maududi, Al-Hukumah al-Islamiyah, h. 137-138.

${ }^{19}$ Said Hawwa, al-Islam, (Beirut: Dar al-Kutub al-Ilmiyah,1979), h. 292 
Suatu UU yang diusulkan oleh Presiden harus diratifikasi oleh dewan syura dan disetujui oleh dewan ahl al-hall wa al-'aqd. Dengan demikian, kedua badan legislatif itu berfungsi sebagai checks and balances terhadap badan eksekutif. Presiden juga bertanggung jawab terhadap rakyat secara umum melalui proses pemilu. Islam menekankan bahwa rakyat mempunyai hak untuk mengontrol Presiden mereka dan menasehatinya dan sekaligus mengkritisinya. ${ }^{20}$ Oleh sebab itu, checks and balances ini dapat berfungsi secara utuh dalam pemerintahan Islam.

\section{Partisipasi Politik}

Pada sistem-sistem politik kontemporer bisa memiliki satu partai (single party), dua partai dominan, sistem multi partai atau nahkan tidak ada partai sama sekali. Ide-ide partai politik ini merupakan perkembangan politik belakangan dan karenanya sarjana muslim klasik tidak pernah mendiskusikan masalah ini.

Sistem politik Islam memberikan setiap penduduk hak untuk terlibat dalam menjalankan urusan-urusan negara, untuk mengekspresikan keyakinan, pikiran dan pendapatnya dengan caracara damai dan untuk menentang penindasan. ${ }^{21}$ Alquran menyebutkan: "kalian bukanlah penyembah apa yang saya sembah. Bagi kalian agama kalian, bagi saya agama saya” (QS.109: 5-6) Menurut Khalid M. Khalid, "rakyat memiliki hak untuk mengekspresikan pendapat dan sikap mereka. Para pemikir politik Islam kontemporer mengatakan bahwa rakyat di negeri Muslim harus menikmati "kebebasan berbicara, kebebasan mengkritik, kebebasan berbuat dan kebebasan ekonomi yang terbatas”. ${ }^{22}$

Berdasarkan atas prinsip kekhalifahan dan keterlibatan publik dalam proses pembuatan kebijakan di negeri Islam, ide referendum atau jajak pendapat untuk meningkatkan partisipasi massa dalam mengatur urusan negara, menjadi

\footnotetext{
${ }^{20}$ Said Hawwa, al-Islam, h. 292.

${ }^{21}$ Ali al-Kawari, “Mafhum al-Dimuqratiyah”, al-Mustaqbal al'Arabi, no. 168, Februari 1993

${ }^{22}$ Khalid M. Khalid, Khulafa al-Rasul, (Beirut: Dar al-Kutub alIlmiyah, 1974), h. 250.
}

metode pembuatan kebijakan yang bisa diterima sepanjang perbuatan tersebut tidak mengharamkan yang halal atau menghalalkan yang haram. ${ }^{23}$

Dengan demikian, dapatlah dipahami bahwa sistem politik Islam cenderung menganut paham demokrasi teokrasi. Disebut teokrasi karena ia didasarkan pada syari'at yang merupakan basis bagi konstitusi negara dan mengikatnya secara moral. Dan disebut demokrasi karena rakyat menikmati hak untuk terlibat secara penuh dalam setiap aspek dari proses menjalankan urusan-urusan negara.

\section{Kritik Terhadap Demokrasi Barat}

Dalam pengertian global, defenisi demokrasi sangat sering disamakan dengan unsur-unsur utama tradisi politik Eropa Barat dan Amerika Serikat. Bagi banyak ilmuwan sosial, pengalaman Barat memberikan landasan bagi defenisidefenisi demokrasi. Dalam konteks itu, seorang ilmuwan terkemuka, Giovanni Sartori mengajukan pertanyaan; ketika kita berbicara tentang pengalaman Barat, apakah kata kuncinya itu 'Barat' atau 'pengalaman '? Dengan kata lain, mungkinkah ada jalan lain menuju demokrasi di luar skenario Barat ?" Jawaban pertanyaan ini didapatkan secara jelas dalam pembahasannya tentang demokrasi di dunia ketiga dan kemungkinannya untuk mengekspor demokrasi. Meskipun demikian ketika menerapkan konsep demokrasi pada kebanyakan dunia ketiga, teutama yang disebut negara-negara sedang berkembang, standarnya menjadi begitu rendah sehigga orang mungkin akan sangsi apakah konsep demokrasi masih layak dipakai.

Demokrasi menurut Woodrow Wilson, merupakan bentuk pemerintahan yang paling sulit. Oleh sebab itu, kita tidak mungkin mengekspor demokrasi model Barat secara 'lengkap'. Sebaliknya, jelas negara-negara baru dan sedang berkembang tidak dapat berlagak seolah-olah telah beranjak pada tahap yang telah dicapai demokrasi Barat. ${ }^{24}$

Contoh di atas dengan jelas menunjukkan identifikasi demokrasi dengan pengalaman Barat

\footnotetext{
${ }^{23}$ Said Hawwa, al-Islam, h. 290

${ }^{24}$ Giovanni Sartori, “Democracy”, dalam karya David L. Sills, ed., International Encyclopedia of Social Science, 1968, h. 118.
} 
yang telah dianut di kalangan analis kontemporer dan diterimanya pola Barat sebagai model yang tepat untuk ditiru oleh seluruh masyarakat. Dalam konteks ini, para ilmuwan sibuk meneliti prospek untuk 'mengekspor demokrasi' dari Barat ke seluruh bagian dunia yang lain. ${ }^{25}$ Bahkan dalam tradisi Barat, demokrasi merupakan istilah yang prinsipnya masih diperdebatkan. Sistem pemilihan umum multi partai dan parlemen yang berlaku di Inggris dan Prancis tidak bisa diterima secara universal sebagai model tunggal demokrasi. Selama revolusi Prancis, misalnya, kaum Babouvis mengembangkan model demokrasi 'antiparlemen plebisitari' yang penting, dan model ini pernah mempengaruhi sistem politik Eropa dalam jangka waktu yang lama. ${ }^{26}$ Sistem alternatif utama di Barat ditawarkan oleh paham Marxis. Marx percaya bahwa pemerintahan demokratis pada dasarnya tidak dapat berjalan di dalam masyarakat kapitalis. Negara pasca kapitalis itu tidak ada kesamaannya dengan rezim parlementer. Parlemen justru menciptakan penghalang antara rakyat yang diperintah dan wakil-wakil mereka. ${ }^{27}$ Akhirnya, dalam prakteknya alternatif-alternatif politik Marxis, mengambil berbagai bentuk, tetapi kebanyakan mewakili secara prinsip satu model demokrasi Barat yang sangat berbeda dengan model Sartori maupun model yang didukung para penentu kebijakan di Amerika Serikat.

Dalam konteks globalisasi dan wacana politik yang lebih luas, arena persaingan menjadi lebih besar lagi. Sepanjang demokrasi dikenali sebagai sebuah gagasan Barat, proses demokratisasi pasti bertentangan dengan pengukuhan identitas komunal tertentu. Suatu upaya untuk membatasi konseptualisasi partisipasi rakyat dalam bidang politik berdasarkan pendekatan kelembagaan khas Barat mengakibatkan pendukung demokrasi Barat dituduh telah melakukan penjajahan budaya. Dengan cara pandang demikian, para pendukung

${ }^{25}$ Enrique Krauze,"England, the United States, and the Export of Democracy", dalam karya Brad Roberts, ed., The New democraticies: Global Change of US. Policy, (Cambridge, Mass: MIT Press,1990), h. 19.

${ }^{26}$ JL.Talmon, The Origins of Totalitarian Democracy, (New York: Frederick A. Praeger, 1960), h. 201-221.

${ }^{27}$ David Held, Models of Democracy, (Stanford, Calif: Stanford University Press, 1987), h. 113, 130. identitas komunal menganggap demokratisasi sebagai proses penerapan pranata dan norma asing kepada masyarakat. Karena itu, persaingan dalam defenisi demokrasi merambah ke pertentangan antara yang 'asing' dan yang 'asli'. ${ }^{28}$

Kalau Wright tidak mendefenisikan demokrasi, maka Lewis dengan singkat menjelaskan demokrasi sebagai "kebijakan pemerintah yang dapat diubah melalui pemilu dan bukan sebaliknya pemilu dapat diubah oleh pemerintah". Namun masalahnya adalah orang-orang Barat ingin menghubungkan defenisi ini dengan model demokrasi mereka, yang sulit diterima secara universal. Mempertanyakan demokrasi Barat seringkali dianggap berbahaya karena dapat diposisikan sebagai anti demokrasi. Sekalipun demikian, harus pula ditegaskan bahwa setidaknya setengah dari polulasi dunia tidak mewarisi demokrasi model ini. ${ }^{29}$

Dari sini tampak bahwa Wright lebih menekankan kajiannya pada pandangan-pandangan para pemikir Muslim kontemporer, sedang Lewis memfokuskan pada praktek Islam di kalangan kaum Muslim secara umum.

Para intelektual Barat seharusnya lebih memikirkan kemungkinan adanya keterbatasan-keterbatasan model demokrasi mereka dibandingkan saat menjalankannya. Sebagai contoh yang patut dipertimbangkan adalah peran uang (money politic) yang makin bertambah besar dan signifikan dalam menentukan calon pejabat di Amerika Serikat yang sering dijadikan model demokrasi ideal. Uang begitu penting dalam budaya politik Amerika hingga (kenyataannya) lebih berpengaruh dibanding individu-individu dalam memilih pejabat negara. Atau perlu dipertimbangkan juga betapa banyaknya negara-negara demokrasi di Barat yang telah gagal dalam mencegah rasisme antara orang hitam dan non semit. Anti semit kenyataannya merupakan produk Barat yang tidak didapati di dunia Islam, yang dibangun oleh wahyu yang diterima tiga Rasul utama, Musa, Isa, dan Muhammad. ${ }^{30}$

Walaupun kebanyakan penulis Barat ber-

\footnotetext{
${ }^{28}$ Bernard Lewis et. al., Islam, Liberalisme, Demokrasi, h. 355.

${ }^{29}$ Bernard Lewis et. al., Islam, Liberalisme, Demokrasi, h. 74.

${ }^{30}$ Bernard Lewis et. al., Islam, Liberalisme, Demokrasi, h. 75.
} 
pandangan bahwa demokrasi merupakan nilai-nilai yang universal, perilaku orang-orang Barat sendiri menunjukkan kesan yang sebaliknya. Perancis misalnya, berperilaku demokratis di negara mereka saja, tapi ketika di Aljazair mereka terlibat selama bertahun-tahun dalam darah kekejaman paling mengerikan di dunia. Ini juga terjadi di bagian Amerika Tengah dan dunia Muslim lainnya akibat kebijakan pemerintahan beberapa negara Barat yang dikomandoi Amerika Serikat yang mempunyai standar ganda, contoh paling mencolok baru-baru ini dengan diabaikannya resolusi DK PBB yang menentang penyerangan ke Iraq yang dalam pemungutan suara $51 \%$ berbanding $49 \%$.

Ketidakkonsistenan Barat ini secara keseluruhan justru memperlemah penerimaan model demokrasi Barat tersebut. Tidak semua masyarakat mendapatkan manfaat dari sistem multi partai. Dalam beberapa hal, pluralisme justru hanya menambah tebalnya kesukuan dan sektarianisme (Rwanda, Sudan, Liberia, dan juga Libanon merupakan contoh yang bisa menjelaskan). Sehingga dapat dipertanyakan pula apakah aturan $51 \%$ adalah solusi yang dapat diterima di kebanyakan masyarakat Afrika dan Asia yang tentunya membutuhkan usaha-usaha dari seluruh partai untuk menerima hasil pemilu.

\section{Demokrasi Dalam Perspektif Islam}

Islam sendiri menggunakan istilah musyawarah sebagai fondasi yang paling utama dalam kehidupan politik. Surat al-Syura ayat 38 menyatakan dengan tegas betapa pentingnya musyawarah:"Dan bagi orang yang mematuhi seruan Tuhannya dan mendirikan shalat, sedang segala perkara mereka (diselesaikan melalui sistem) musyawarah di antara sesama mereka”. Mengomentari konsep musyawarah ini, Yusuf Ali seperti pernah diungkapkan Nurcholis Majid menyatakan:

"Musyawarah, inilah kata-kata kunci dalam surat ini, da menunjukkan cara idealyang harus ditempuh oleh seorangyan baik dalam berbagai urusannya, sehingga di satu pihak kiranya ia tidak menjadi terlalu egois, dan di pihak lain ia tidak dengan mudah meninggalkan tanggung jawabyang dibebankan atas dirinya sebagai pribadi yang perkembangannya akan diperhatikan dalam pandangan Tuhan...Prinsip ini sepenuhnya dilaksanakan oleh Nabi dalam kehidupan beliau, baik pribadi maupun umum, dan sepenuhnya diikuti oleh para penguasa Islam masa awal. Pemerintahan perwakilan modern adalah suatu percobaan yang tidak bisa disebut sempurna untuk melaksanakan prinsip itu dalam urusan negara"31

Selanjutnya dalam surat Ali Imran ayat 159 dinyatakan pula betapa pentingnya musyawarah dalam Islam, firman Allah:

"Maka disebabkan oleh rahmat Allahlah kamu berlaku lemah lembut terhadap mereka. Sekiranya kamu bersikap keras lagi berhati kasar, tentulah mereka menjauhkan diri dari sekelilingmu. Karena itu maafkanlah mereka, mohonkan ampun bagi mereka dan bermusyawarahlah dengan mereka dalam urusan itu. Kemudian apabila kamu telah membulatkan tekat, maka bertawakallah kepada Allah, sesungguhnya Allah menyukai orang-orang yang bertawakal kepada-Nya."

Begitu juga dalam persamaan derajat yang merupakan bagian dari unsur demokrasi, dalam surat al-Hujurat ayat 13 dinyatakan:

"Hai manusia, sesungguhnya Kami menciptakan kamu dari seorang pria dan wanita dan menjadikan kamu berbangsa-bangsa dan bersuku-suku supaya kamu saling mengenal. Sesungguhnya orang yang paling mulia di sisi Allah ialah orang yang paling bertakwa di antara kamu. Sesungguhnya Allah Maha Mengetahui lagi Maha Mengenal”

Dalam sebuah hadis juga pernah diriwayatkan bahwa Nabi secara tegas menyatakan tidak ada kelebihan antara orang Arab dan orang yang bukan Arab, yang membedakan antara manusia yang satu dengan manusia lainnya adalah ketakwaannya kepada Allah. Di dalam menjalankan roda pemerintahan, Nabi Muhammad kemudian merumuskan apa yang dikenal sebagai "Konstitusi

${ }^{31}$ Nurcholis Madjid, Islam, Doktrin, dan Peradaban, (Jakarta: Yayasan Paramadina,1992), h. 560-561. 
Madinah” yang menjamin persamaan hak antara berbagai suku yang ada pada waktu itu dan mensyaratkan adanya satu persatuan sebagai landasan dalam hidup bernegara. Tidak hanya itu, Nabi Muhammad menyatakan dengan tegas pula bahwa kaum wanitapun seperti halnya kaum pria mempunyai hak untuk ikut berperang kalau keadaan memungkinkan"32

Nabi Muhammad dalam memutuskan segala sesuatu selalu berpedoman pada al-Quran, namun dalam hal-hal yang tetentu yang belum diatur dalam Alquran, beliau tidak jarang mengajak musyawarah para sahabatnya. Hal ini pernah diungkapkan Thaha Husein sebagaimana dikutip Nurcholis Madjid:

“...ketika Nabi saw menempatkan (pasukan) sahabat pada suatu posisi sewaktu perang Badar, kemudian Hubab ibn al-Mundzir ibn al-Jamuh bertanya: "ini perintah yang diturunkan Allah kepada engkau atau pendapat dan musyawarah" Nabi menjawab: "ini hanyalah pendapat dan musyawarah”. Maka dia (al-Hubab) menyarankan kepad Nabi posisi lain yang lebih cocok untuk kaum muslim, dan Nabi menerima sarannya itu.”33

Kalau dikaitkan dengan konteks negara modern yang jauh lebih kompleks seperti sekarang ini, proses musyawarah yang dijalankan pada zaman Nabi sebenarnya secara substantif tidak berbeda dengan apa yang diperlihatkan dalam proses politik saat ini, yaitu apa yang dikenal dengan representative democracy, karena kita juga memahami bahwa Nabi melakukan musyawarah tidak melibatkan semua warga masyarakat yang telah memiliki 'political franchise', akan tetapi musyawarah yang melibatkan para sahabat yang tentu saja sangat berpengaruh dalam lingkungan masyarakatnya.

Begitu juga pada saat perjanjian Hudaibiyah, Nabi memperlihatkan toleransi yang sangat luar biasa meskipun terhadap lawan politiknya. Pada waktu itu Nabi akan enjalankan Umrah dengan dengan para pengikutnya. Karena tujuannya adalah ibadah, maka Nabi tidak membawa senjata seperti

${ }^{32}$ Munawir Syadzali, Islam and Governmental System, (Jakarta: INIS, 1991), h. 11.

${ }^{33}$ Nurcholis Madjid, Islam, Doktrin..., h. 561. halnya orang berperang.. Ketika akan memasuki kota Mekah, Nabi berhenti di lembah Hudaibiyah untuk mengamati prilaku kaum Quraisy dan mengadakan negosiasi dengan mereka. Sekalipun negosiasi sudah dilakukan berkali-kali, persetujuan tampaknya sulit tercapai karena begitu kakunya utusan kaum Quraisy mempertahankan prinsipprinsip mereka. Begitu tolerannya Nabi terhadap prilaku utusan Quraisy Suhail ibn Amr sehingga menimbulkan rasa sangat dongkol para sahabat Nabi, terutama Umar ibn al-Khattab. ${ }^{34}$

Toleransi Nabi dalam bermusyawarah juga tampak setelah Islam menang dalam perang Badar. Nabi mengajak para sahabatnya bermusyawarah menangani para tawanan perang yang cukup banyak. Abu Bakar dan beberapa sahabat lain mengusulkan agar tawanan perang tersebut dijadikan sandera untuk ditukar dengan sejumlah uang bagi kebebasan mereka, sebab umat Islam kala itu sedang membutuhkan biaya dan kebetulan di antara tawanan itu ada yang kaya raya. Sedang Umar mengusulkan agar mereka semua dibunuh sebagai balasan setimpal atas kekejian mereka terhadap Nabi dan umat Islam, terutama paman Nabi yaitu Abbas dan saudara Ali ibn Abi Thalid yaitu Aqib ibn Abu Thalib. Setelah mendengarkan dan memperhatikan pendapat para sahabatnya, maka Nabi lalu memutuskan agar mereka dibebaskan dengan tebusan, dan bagi yang tidak mampu membayar tapi punya kemampuan baca tulis wajib mengajarkan kepada kaum muslim di Madinah hal-hal yang berkaitan dengan baca tulis. ${ }^{35}$

Menurut Soroush, walaupun Islam secara literal berarti kepatuhan, ia berargumen bahwa tidak ada kontradiksi antara Islam dan kebebasan-yang terkandung dalam demokrasi. Islam dan demokrasi tidak hanya sejalan, tapi juga hubungan keduanya tak dapat dielakkan. Dalam masyarakat Muslim, satu tanpa yang lainnya takkan sempurna. ${ }^{36}$

Pembelaannya terhadap demokrasi untuk dunia Islam bersandar pada dua pilar (dasar): ${ }^{37}$ Pertama, untuk menjadi Mukmin sejati seseorang harus

\footnotetext{
${ }^{34}$ Munawir Syadzali, Islam and Governmental System, h. 12-13.

${ }^{35}$ Bernard Lewis, et al., Islam, Liberalisme, Demokrasi, h. 124.

${ }^{36}$ Bernard Lewis, et al., Islam, Liberalisme, Demokrasi, h. 66.

${ }^{37}$ Bernard Lewis, et al., Islam, Liberalisme, Demokrasi, h. 67.
} 
bebas. Keimanan yang diterima di bawah ancaman atau paksaan adalah keimanan palsu. Dan jika seorang mukmin secara bebas tunduk (tunduk berkonotasi berlawanan dengan kata bebas), ia juga dapat secara bebas meninggalkan keimanannya. Kontradiksi yang sesungguhnya hanya ketika bebas untuk tunduk dan kemudian membuang kembali kebebasan.

Kebebasan ini merupakan dasar dari demokrasi. Lebih lanjut Soroush menyatakan bahwa keimanan dan kehendak mayoritas rakyat harus mebentuk negara Islam ideal (sempurna). Demokrasi Islam tidak dapat dibentuk dari atas. Demokrasi hanya diakui jika dipilih oleh mayoritas rakyat, meliputi kaum Mukmin dan non Mukmin.

Kedua, menurut Soroush, pemahaman kita mengenai agama terus berkembang. Teks-teks kitab suci tidak berubah tapi penafsirannya selalu berubah akibat pemahamannya dipengaruhi oleh kondisi dan zaman orang beriman. Jadi tidak ada penafsiran yang mutlak (benar) dan menyeluruh bagi seluruh waktu dan tempat. Lebih dari itu, setiap orang diberikan hak (yang sama) bagi pemahamnnya (mengenai agama): Tidak ada sekelompok orangpun (termasuk kaum ulama) yang mempunyai hak istimewa dalam menafsirkan ajaran-ajaran keimanan. Beberapa penafsiran mungkin lebih diterima dibandingkan yang lain, tetapi tidak satupun memiliki otoritas terhadap yang lain.

Menurut Ghannouchi, demokrasi Islam awalnya merupakan penafsiran terhadap teks-teks kitab suci. Islam tidak datang dengan membawa program khusus berkenaan dengan hidup manusia. Islam membawa prinsip-prinsip umum. Kewajiban manusia untuk membentuk program/sistem ini melalui persentuhan antara-prinsip-prinsip Islam dan modernitas. Seorang muslim dijamin haknya dalam menafsirkan teks-teks Alquran. Wewenang mereka telah sempurna sejak Islam tidak berbentuk lembaga atau individu yang mempunyai otoritas dalam ajaran-ajaran agama. Proses musyawarah, selanjutnya berarti bahwa membuat keputusan merupakan milik masyarakat seluruhnya. Nilai-nilai demokrasi dari keberagaman politik dan toleransi secara sempurna ini cocok sekali dengan Islam. ${ }^{38}$

Kekuatan hukum negara Islam kontemporer berdasar pada kebebasan (kemedekaan) dari koloni Eropa modern. Dalam hal ini, baik sekuler, Muslim, dan Kristen bekerja bersama-sama untuk kemerdekaan. Tidak ada tempat untuk membuat perbedaan antar warga, dan hak-hak persamaan merupakan dasar bagi masyarakat Muslim baru manapun. Sedang kekuatan dan legitimasi hukum muncul hanyalah melalui pemilu. Ia mengakui bahwa pengalaman-pengalaman Islam di sekitar persamaan dan partisipasi memang telah ternodai. Masyarakat muslim dahulu dibangun berdasarkan atas penaklukan. Tapi dia berkilah bahwa keimanan secara tradisional juga telah mengenalkan ajaran pluralis internal. Ia mencontohkan berkurangnya perang keyakinan antar muslim sebagai bukti penerimaan Islam akan perbedaan. Berdasarkan keterangan dari Alquran 49:13, ia menjelaskan bahwa Islam melarang menggunakan agama untuk tujuan materi dan duniawi. Robin Wright dan Bernard Lewis memiliki sejumlah gagasan yang bisa diterima akal dan benar mengenai sifat demokrasi Islam. Dalam pengamatan mereka, Islam tidak selalu harus dilawankan vis-à-vis pemerintahan perwakilan.

Bagi kebanyakan orang Barat, konsep 'demokrasi Islam' merupakan suatu anatema. Pendapat ini memustahilkan untuk memahami daya tarik dan kekuatan gerakan-gerakan Islam. Mengingat demokrasi merupakan konsep yang pada dasarnya masih diperdebatkan, penting dipahami bagaimana persepsi demokrasi di kalangan gerakan kebangkitan Islam belakangan ini. Pemahaman ini penting bukan bagi mereka yang memandang kebangkitan Islam sebagai ancaman, sebab kelompok ini perlu juga memahami keragaman defenisi tentang demokrasi. Barangkali, bahkan lebih penting lagi bagi kelompok semacam itu, sebab seperti disarankan Gallie tiga dasawarsa lalu, para pendukung demokrasi di Barat mungkin dapat mempelajari sesuatu mengenai demokrasi dari pihak-pihak lain. Dalam lingkungan global dewasa ini, pemahaman yang sempit dan picik atas konsep yang sedemikian penting seperti

\footnotetext{
${ }^{38}$ Bernard Lewis, et al., Islam, Liberalisme, Demokrasi, h. 71.
} 
demokrasi, sangatlah berbahaya dan bahkan dapat menghambat sistem-sistem demokrasi yang telah lama mapan. ${ }^{39}$

\section{Hubungan Islam dan Demokrasi}

Hubungan antara Islam dan demokrasi, atau dengan kata lain potensi Islam demokratik sebagai agama, budaya, dan peradaban selalau menjadi isu kontroversial. Dalam sebuah perdebatan, teori dan praktek tidak selalu terpisah, seperti juga masalah-masalah agama dan kultur politik. Sebagian orang melihat Islam sebagai doktrin (real Islam), seperti yang ada dalam ayat Alquran dan al-Sunnah yang otentik, sementara yang lain melihat Islam sebagai apa yang disebut "Islam dalam sejarah”. Yakni Islam yang dipahami dan dijalankan oleh kaum Muslim. Ada juga kalangan yang umumnya dikelompokkan sebagai Islamis yang melihat Islam sebagai agenda politik yang mampu menyaingi dan bahkan lebih baik dari ideologi sekuler. ${ }^{40}$

Seringkali kita dihadapkan dengan kenyataan adanya kesalahan persepsi bagaimana hubungan antara Islam dan negara, atau secara khusus hubungan antara Islam dan demokrasi. Hal ini terjadi karena bersumber dari ketidakpahaman orang terhadap Islam dan juga karena pada saat sekarang ini tidak ada satu negarapun di dunia modern yang mencoba menjalankan ajaran Islam dengan benar dan konsekuen sehingga tidak ada yang menjadi sumber acuan untuk itu. ${ }^{41}$

Masalah kompatibilitas Islam dengan demokrasi sebenarnya dapat ditilik dari berbagai sudut pandang. Kontroversi yang terjadi belakangan antara para pemikir Muslim dan Barat menyangkut hubungan antara Islam sebagai agama wahyu dan demokrasi sebagai bentuk pemerintahan modern, memunculkan sebuah slogan bahwa Islam juga menawarkan sebuah format tertentu tentang politik dan pemerintahan. Perdebatan itu juga memperlihatkan bahwa sejauh ini sebagian besar pemerintahan tempat kaum Muslim hidup, di-

${ }^{39}$ Bernard Lewis, et al., Islam, Liberalisme, Demokrasi, h. 349.

${ }^{40}$ Bernard Lewis, et al., Islam, Liberalisme, Demokrasi, h. 93.

${ }^{41}$ Bernard Lewis, et al., Islam, Liberalisme, Demokrasi, h. 116. bangun di atas prinsip-prinsip Islam. Dan dalam banyak hal, dengan mudah bisa ditunjukkan bahwa baik gaya hidup maupun berbagai tulisan tentang Islam, sama sekali tidak kompatibel dengan demokrasi liberal.

Mengenai hubungan antara agama dan demokrasi, Komaruddin Hidayat membaginya menjadi tiga model: 42

Pertama, model paradoksal atau model negatif, menyatakan bahwa antara agama dan demokrasi tidak bisa dipertemukan bahkan berlawanan. Di antara tokoh penganut paham ini ialah Karl Marx, Max Weber, Nietzche, dan Sartre. Mereka beragumen bahwa secara historis-sosiologis, sejarah agama memberikan gambaran peran agama tidak jarang hanya digunakan oleh penguasa politik dan pimpinan organisasi keagamaan untuk mendukung kepentingan kelompok. Selain itu, secara filosofis yang menyatakan bahwa keterikatan pada doktrin agama akan menggeser otonomi dan kemerdekaan manusia, yang berarti pula menggeser prinsip-prinsip demokrasi. Sedangkan secara teologis menegaskan bahwa agama bersifat deduktif, metafisis dan menjadikan rujukannya pada Tuhan—padahal Tuhan tidak hadir secara empiris, konkrit dan dinamis. Maka agama tidak mempunyai kompetensi menyelesaikan persoalan demokrasi. Hanya ketika agama disingkirkan, maka manusia akan lebih leluasa, mandiri dan jernih berbicara soal demokrasi. ${ }^{43}$ Jadi bagi kelompok pertama ini agama justru dianggap sebagai penghalang lahirnya iklim demokrasi dalam interaksi sosial kehidupan manusia. Kedua, model sekular atau model netral, yang menyatakan bahwa hubungan agama dengan demokrasi bersifat netral, urusan agama dan politik termasuk masalah demokrasi berjalan sendirisendiri. Karena itu peran agama bagi manusia hanya terbatas pada hubungan manusia secara pribadi dengan Tuhannya dan pencarian makna hidup dan kehidupan. Sedangkan dalam interaksi sosial, nilai-nilai demokrasi seperti dalam kehidupan politik dijadikan sebagai tata krama dan etika sosial,

${ }^{42}$ Komaruddin Hidayat, Tiga Model Hubungan Agama dan Demokrasi, dalam Elza Peldi Taher, Demokratisasi Politik, Budaya dan Ekonomi, Jakarta, 1994, h. 189.

${ }^{43}$ Bernard Lewis, et al., Islam, Liberalisme, Demokrasi, h. 192. 
dan dalam hal ini agama tidak dapat memainkan perannya. Masyarakat modern yang mendukung sekularisasi politik tidak mesti dihakimi sebagai menolak dan anti agama, karena orang modern tetap beragama. Namun kehadiran agama secara formal institusional dalam politik tidak diterima, karena hal ini seringkali membuat agama mudah dipolitisasi untuk kepentingan politik. ${ }^{44}$ Jadi dalam pandangan kedua ini antara agama dan demokrasi tidak terdapat titik singgung, ajaran agama tidak masuk dalam wilayah publik, dan negara tidak pula mengurus masalah agama. Ketiga, model teodemokrasi atau model positif, yang menyatakan bahwa agama dan demokrasi mempunyai kesejajaran dan kesesuaian. Menurut pandangan ini, agama secara teologis dan sosiologis sangat mendukung proses demokratisasi politik, ekonomi maupun kebudayaan..$^{45}$ Senada dengan hal di atas, Masyhur Amin dan Mohammad Najib menyatakan bahwa agama sebagai ajaran normatif dalam banyak hal mempunyai singgungan terhadap nilainilai demokrasi, sehingga interaksi antara keduanya bisa saling mendukung. Keberadaan agama dapat menjadi roh sekaligus inspirasi bagi demokrasi. Banyak ajaran agama yang sangat relevan dengan ajaran demokrasi ${ }^{46} \mathrm{Hal}$ ini diindikasikan dengan suatu bukti bahwa kehadiran semua agama dengan misi profetiknya (misi profetik agama antaa lain pembebasan, keadilan, kedamaian) senantiasa membawa imbas pada perombakan struktur masyarakat yang dicekam oleh kekuasaan yang despotik, tiranik, zhalim dan otoriter menuju terwujudnya struktur dan tatanan masyarakat yang demokratis.

Dalam kaitannya dengan nilai-nilai demokratis dalam agama, khususnya agama Islam, Ernest Gellner menyatakan bahwa dalam agama Islam ada kesamaan unsur-unsur dasar (family remblences) dengan demokrasi. Begitu pula pandangan Robert N. Bellah yang sampai pada suatu kesimpulan bahwa penyelenggaraaan pemerintahan yang

${ }^{44}$ Umaruddin Masdar, dkk., Mengasah Naluri Publik Memahami Nalar Politik, (Yogyakarta: LKIS, 1999), h. 89.

${ }^{45}$ Umaruddin Masdar, dkk., Mengasah Naluri..., h. 90.

${ }^{46}$ M. Masyhur Amin dan Mohammad Najib, Agama, Demokrasi, dan Transformasi Sosial, (Yogyakarta: LKPSM, 1993), h. vii. dikembangkan oleh Nabi Muhammad saw di Madinah bersifat egaliter dan partisipatif, dan sebagai bentuk negara modern. Unsur-unsur dasar yang dimaksudnya ialah doktrin Islam tentang keadilan (al-'Adl), egalitarian (al-Musawah), musyawarah (al-Syura) yang terealisir dalam praktek politik kenegaraan awal Islam. ${ }^{47}$

\section{Menuju Demokrasi Islam}

Para pemikir politik Islam abad 19, yang secara nyata dipengaruhi oleh pemikiran dan praktek demokrasi Eropa, berupaya mempersamakan antara konsep demokrasi dan konsep Islam tentang syura ketika menghadapi krisis pemerintahan yang dipicu oleh otokrasi dan tindakan korup para pemimpin muslim, mereka mencari legitimasi dengan meminjam aspek-aspek model Barat yang mereka yakini kompatibel dengan Islam dan mampu menyelesaikan krisis. ${ }^{48}$

Salah satu persoalan paling menarik dalam perdebatan mengenai Islam, negara, dan demokrasi adalah perbedaannya yang seringkali dibuat oleh para ilmuwan Muslim dan kaum Islamis antara "nilai-nilai (values)" di satu sisi dan teknik (techniques)" di sisi lain. Teknik dianggap netral dari pandangan agama dan atau moral (secara teknis disebut mubah). Oleh sebab itu, ia dapat diambil dan diadaptasi secara bebas dari kultur serta masyarakat non Islam, selama nilai-nilai Islam tetap dipertahankan secara utuh dan tidak diganggu gugat. Argumen tersebut dikenal melalui diskusi mengenai budaya, pembangunan, dan teknologi modern. Argumen ini terutama relevan untuk konteks saat ini, karena demokrasi secara umum. Dan liberal, pluralis secara khusus jelas sekali memasukkan baik teknik dan nilai. Dan adalah demokrasi liberal dan pluralis inilah yang ada dalam pikiran sebagian besar Muslim dan Islamis saat mereka berbicara dan menulis tentang demokrasi serta kesesuaiannya bagi masyarakat Islam, apakah mereka menerimanya dengan hati-hati, dengan

\footnotetext{
${ }^{47}$ Bahtiar Effendy, "Demokrasi dan Agama: Eksistensi Agama dalam Politik Indonesia”, dalam M. Deden Ridwan dan Asep Gunawan, Demokrasi Kekuasaan, (Jakarta: LSAF-TAF, 1999), h. 140.

${ }^{48} \mathrm{M}$. Fathi Othman, Min Ushul al-Fikr al-Siyasi, (Beirut: al-Risalah, 1984), h. 48.
} 
hangat, atau menolak secara terang-terangan. Perbedaan yang ada menimbulkan masalah yang cukup serius yang tidak selalu dapat diselesaikan dengan kekakuan.

Perbedaan lainnya yang juga cukup menarik dan memang terkait erat, membutuhkan klarifikasi yaitu perbedaan antara hal-hal yang esensisal atau fundamental dari agama (al-Ashl) dan "derivasiderivasi” norma-norma positif, sesuatu yang bisa dikatakan non esensial (al-Furu') atau antara elemen Islam yang tetap (al-tsabit) dan elemen yang fleksibel (al-mutaghayyir). Apabila yang pertama sudah didefenisikan untuk semua waktu dan tempat, melalui kehendak dan firman Yang Kuasa (al-nash), maka yang terakhir haruslah diperoleh melalui akal manusia (walaupn tidak ada akal manusia yang bebas dari batasan-batasan keyakinan) dari ayatayat suci. Mereka meniscayakan adanya interpretasi terstruktur (ijtihad) terhadap wahyu dan hadis.

Perbedaan tersebut lebih nyata lagi karena sebagian besar muslim dan hampir semua penulis muslim yang menulis mengenai Islam dan demokrasi atau tatanan Islam yang ideal menganut pandangan bahwa Islam adalah agama dan negara (al-Islam Din wa Daulah) atau agama dan dunia (Din wa Dunya). Banyak kalangan menganggap tidak ada persoalan dengan implikasi luas dari tesis tersebut, tetapi banyak pula yang mempermasalahkannya. Mengikuti pembaharu Mesir Muhammad Abduh (1849-1905) yang pendekatan modernnya hingga kini masih menjadi inspirasi pemikiran Islam kontemporer, Muhammad Immarah memformulasikan suatu kompromi: yang menyatakan bahwa dua ruang tersebut, agama (ibadah, ritual) dan politik harus dibedakan, tetapi berada dalam undang-undang/ hukum moral dan religius yang sama, yaitu syari'ah (“tidak terpisah...tetapi berbeda”, sebagaimana dikatakan Abduh).

Sebagian kaum sunni sepakat bahwa pemerintah atau pemerintahan (al-hukm) merupakan bagian dari tugas-tugas sosial, hubungan muamalah, dan oleh karena itu dapat diubah. Mekanisme dan prosedurnya dapat diadaptasi dari sumbersumber non Islam selama hasilnya masih sesuai dengan norma-norma dan nilai-nilai Islam, dengan tidak mengabaikan, bertentangan, atau bahkan melanggar perintah Tuhan dan Rasul-Nya (nash), yaitu Alquran dan al-Sunnah. ${ }^{49}$ Asumsi ini memiliki jangkauan implikasi yang jauh dengan membolehkan fleksibilitas yang luas pada masalahmasalah sosial dan pengaturan politik, yang pada dasarnya dianggap teknis belaka, digunakan pada tujuan-tujuan tertentu (nilai). Tuhan dianggap telah membiarkan komunitas muslim untuk menentukan sendiri detail-detail pengaturan politik sesuai dengan berbagai kebutuhan dan aspirasi mereka. Bahkan Tuhan tidak mengaruniai anak bagi Rasul sebagai bukti, dengan demikian tidak ada kekuasaan warisan. Sebagai gantinya adalah konsultasi (syura), pemilihan secara bebas, dan menurut beberapa orang dianggap demokrasi. Sesuai dengan pandangan tersebut, khalifah memang memberikan satu model pengaturan politik, tetapi bukan satu-satunya, dan mungkin bahkan bukan yang terbaik dan sesuai dengan tuntutan serta kenyataan abad 20. Sehingga hal itu bukanlah unsur yang menentukan untuk dijadikan tatanan sosial politik yang telah ada ke dalam tatanan Islami.

Sebagaimana yang sudah diketahui bahwa ciri tatanan Islam adalah syari'ah, yang terdiri dari aqidah, hukum, dan etika yang nilai-nilainya diabadikan. Para Islamis berargumen bahwa tidak ada negara yang dapat mengklaim dirinya sebagai negara Islam tetapi tidak mengamalkan syari'ah. Berangkat dari pemahamannya terhadap ayat Alquran (5: 44,45 dan 47), Islam radikal dan militan akan berusaha keras mendeklarasikan diri sebagai pewaris dan mengeluarkan dari komunitas, siapapun yang tidak mengikuti hukum Allah, yang mereka identifikasikan sebagai syari'ah. Syari'ah memasukkan sistem nilai tatanan Islam dan memberinya tujuan moral dan politik, hanya apabila syari'ah menjadi hukum yang memadukan legalitas dan legitimasi. Sebab tidak ada legitimasi tanpa syari'ah (la syar'iyah di duni syari'ah). Negara atau tatanan Islam yang yang didasarkan pada syari'ah itulah satu-satunya negara tempat wanita dan pria

${ }^{49}$ Said Hawwa, Al-Islam, h. 24-49. 
memiliki kesamaan hukum (abadi dan ketuhanan) ${ }^{50}$

Banyak pikiran dicurahkan untuk membahas masalah bentuk dan prosedur syura, partisipasi sebagai konsultasi. Syura, pada kenyataannya telah mengalami reinterpretasi yang luas sehingga secara umum dipandang sebagai padanan Islam (otentik) dengan demokrasi parlementer modern. ${ }^{51}$ Pertanyaannya adalah apakah kaum muslim secara umum dan Islamis secara khusus mau menganut penafsiran seperti ini.

Bahkan setelah debat intensif, banyak pertanyaan kontroversial: apakah pemimpin memiliki tugas untuk bermusyawarah, dan apakah ia terikat oleh keputusan mereka yang diajak musyawarah; apakah mereka adalah orang-orang yang dipilihnya sendiri, anggota elit sosial dan politik ulil amri atau ahlu al-halli wa al-aqdi (dalam menggunakan terminologi tradisional), atau wakil yang dipilih oleh masyarakat; hanya individu saja atau anggota dari organisasi formal seperti partai politik, perserikatan dagang, organisasi tani dan sebagainya; ahli agama, ulama, dan fuqaha atau ahli bidang lain dan pemimpin masyarakat; apakah mereka memutuskan berdasarkan peraturan terbanyak dan apakah semua masalah kepentingan umum harus menjadi materi yang dikonsultasikan secara resmi. Kebanyakan penguasa cenderung menilai syura sebagai sesuatu yang diwajibkan dan mengikat penguasa wajibah dan mulzimah, melibatkan ahli keagamaan sebagaimana pemimpin masyarakat lainnya, dan menerima putusan terbanyak sebagai hal yang norma dan sah. Bergerak jauh melampaui preseden sejarah, mereka menganggap syura sebagai proses formal dan institusi, misalnya Dewan Syura dibentuk dari wakil masyarakat terpilih, atau boleh disebut juga parlemen Islam. ${ }^{52}$

Said Hawwa menganggap bahwa demokrasi yang terkadang diidentikkan dengan syura tersebut bukanlah sebagai tujuan, melainkan suatu cara untuk sampai kepada apa yang diyakini sebagai tujuan yang paling mulia, yaitu penerapan syari'at Islam. Ia menyatakan:"Pengalaman telah

\footnotetext{
${ }^{50}$ Bernard Lewis et. al., Islam, Liberalisme, Demokrasi, h. 100

${ }^{51}$ Bernard Lewis et. al., Islam, Liberalisme, Demokrasi, h. 108.

52 Bernard Lewis et. al., Islam, Liberalisme, Demokrasi, h. 109.
}

membuktikan bahwa di dalam diri umat Islam, demokrasi adalah mudharat yang paling kecil sebelum sampai kepada negara Islam. ${ }^{33}$

Dengan demikian, yang harus ditekankan adalah musyawarah ideal yang dijalankan secara harmonis dan wajar dengan melihat syura sebagai instrumen untuk menjaga persatuan, bukan forum debat, kontes dan kompetisi, tapi mencerminkan kepercayaan, pandangan dunia dan mengakomodasi berbagai kepentingan yang berbeda. Hal yang paling akhir dari semua ini; kepentingan sesaat harus disingkirkan sedapat mungkin seperti keegoisan, tindakan yang bersifat memecah belah, merusak yang disebut Alquran sebagai hawan dan keinginan atau ambisi berlebihan yang bertentangan dengan Islam. Akhirnya hanya ada satu kepentingan yang benar, dan itu adalah kepentingan masyarakat secara keseluruhan dan atau kepentingan Islam (dan di dalam teorinya tidak akan ada kontradiksi antara keduanya, karena masyarakat beriman tidak akan khilaf dan karenanya tidak akan menyimpang dari takdir).

Untuk mendapatkan kebaikan masyarakat, almashlahah al-'ammah (kepentingan umum) tetap menjadi tujuan pokok yang harus dilaksanakan, sementara kepentingan individu tertentu harus dikesampingkan. Cita-cita persatuan (wahdah), konsensus (ijma'), dan keseimbangan yang harmonis di dalam kelompok-kelompok dan kepentingankepentingan (tawazun), sering dihubungkan dengan konsep teologi tauhid, keesaan Tuhan, masih merupakan hal yang penting. Persatuan bertentangan dengan perselisihan, konflik, dan anarkhi, serta konsensus sangat membenci fitnah. ${ }^{54}$ Hal tersebut membatasi pluralisme yang absah yang telah disuarakan dengan jelas dalam debat tentang kebebasan berpikir, bertindak, berbicara dan berkumpul, yang menjadi domain hak asasi manusia.

Wacana yang dikembangkan kaum muslim atau kalangan Islamis tentang Islam dan demokrasi ternyata tidak hanya mengadopsi-dan dinyatakan sebagai Islami atau sesuatu yang cocok dengan

\footnotetext{
${ }^{53}$ Said Hawwa, Al-Islam, h. 105.

${ }^{54}$ Bernard Lewis et. al., Islam, Liberalisme, Demokrasi, h. 110.
} 
Islam-unsur-unsur tertentu dari organisasi demokrasi politik; seperti pemilu, representasi, aturan-aturan parlementer, atau pemisahan kekuasaan. Ia juga menggabungkan setidaknya dalam satu level, nilai-nilai kunci seperti kebebasan, persamaan, tanggung jawab individu dan akuntabilitas, meskipun analisis sikap kalangan Islamis terhadap hak-hak manusia, wanita, kaum non muslim, pemikir bebas, orang-orang agnotis, dan ateis akan menyatakan bahwa prinsip-prinsip umum (tidak ada paksaan dalam agama, kebebasan berpendapat, persamaan derajat, dan lainnya) dalam banyak kasus dibatasi pada kerangka Islam Syari'ah, etika bersama, atau bergantung bagaimana kelompok individu pemikir atau aktivis memilih untuk mendefenisikan hal tersebut.

\section{Penutup}

Sejarah memang selalu mengundang tafsir yang berbeda. Ia bisa dibaca atau disalahpahami untuk menguatkan suatu pandangan tertentu. Apa yang disebut Konstitusi Madinah telah dipakai oleh mereka yang berargumen bahwa komunitas teladan telah dibangun oleh Nabi Muhammad secara demokratis, dengan konsultasi (syura) sebagai sesuatu yang wajib, bahkan bagi Rasul sendiri. Adapun hak kewargaan diberikan secara adil kepada baik Muslim maupun non Muslim. Menurut paham ini, Madinah merupakan model ideal suatu negara Islam yang berdasarkan syura dan persamaan.

Tampaknya telah muncul kesepakatan umum di kalangan mainstream Islamis bahwa demokrasi merupakan spirit sistem pemerintahan Islam, walaupun mereka menolak asumsi filosofis demokrasi Barat yang menyebutkan bahwa kedaulatan berada di tangan rakyat. Mereka tetap berpendapat, pilihan mayoritas hanya bisa

membentuk basis bagi penggunaan otoritas politik secara absah dalam suatu negara Islam, bila ia mengakui dan tetap dalam parameter-parameter politik dan kedaulatan Tuhan. Kalangan Islamis juga menegaskan, karena Tuhan memerintahkan kaum muslim untuk mengelola urusan-urusan kolektif melalui musyawarah (syura) dan memberikan keistimewaan kepemimpinan kepada seluruh masyarakat muslim, bukan pada satu orang, kelompok tertentu atau kelas tertentu, maka pemilihan pemimpinnya haruslah didasarkan atas kehendak massa muslim.

Sebuah demokrasi yang "Islami” tidaklah hanya merangkul nilai-nilai sekuler yang diadopsi dari Barat. Namun langkah awal yang harus diambil adalah memasukkan proses institusionalisasi di dalam Islam. Keterlibatan Islam yang terinstitusionalisasi dalam proses pembangunan akan membantu cita-cita demokrasi sehingga kaum Islamis dapat sukses menentang hegemoni pemahaman kaum tradisionalis baik di dalam arena agama maupun politik. Untuk bermain dalam percaturan demokrasi, pemimpin-pemimpin agama akan lebih baik mengorganisasi diri mereka sendiri terlebih dahulu, untuk kemudian mengajukan rencana-rencana alternatif untuk isu-isu sosioekonomi dan politik yang dihadapi bangsa. Hal ini dapat membantu mereka mempertahankan legitimasi dan dukungan rakyat, yang memfasilitasi perjuangan mereka demi kekuasaan politik. Sebab organisasi adalah salah satu kunci keberhasilan berbagai kelompok untuk mencapai tujuannya, termasuk untuk merealisasikan demokrasi yang Islami.

\section{Pustaka Acuan}

Abdillah,Masykuri, Demokrasi di Persimpangan Makna: Respon Intelektual Muslim Indonesia Terhadap Konsep Demokrasi (1966-1993), Yogyakarta: Tiara Wacana, 1999

Amin, M. Masyhur dan Mohammad Najib, Agama, Demokrasi, dan Transformasi Sosial, Yogyakarta: LKPSM, 1993

Budiardjo, Miriam, Demokrasi di Indonesia: Demokrasi Parlementer dan Demokrasi Pancasila, Jakarta: Gramedia, 1996

Dahl, Robert, Modern Political Analysist, EnglewoodCliffs, NJ: Prentice Hall, 1976, edisi ketiga.

Dahl, Robert, Polyarchy, Participation and Opposition, New Haven, Conn: Yale University Press, 1971 
Effendy, Bahtiar, Demokrasi dan Agama: Eksistensi Agama dalam Politik Indonesia, dalam M. Deden Ridwan dan Asep Gunawan, Demokrasi Kekuasaan, Jakarta: LSAF-TAF, 1999

al-Ghazali,Muhammad, Huquq al-Insan ibn Ta'alim al-Islam wa Mitsaq al-Umam al-Muttahidah, Cairo: Dar al-Kitab al-Hadits,1965

Hawwa,Said, al-Islam, Beirut: Dar al-Kutub al'Ilmiyah, 1979

Held, David, Models of Democracy,Stanford, Calif: Stanford University Press, 1987

Hidayat,Komaruddin, Tiga Model Hubungan Agama dan Demokrasi, dalam Elza Peldi Taher, Demokratisasi Politik, Budaya dan Ekonomi, Jakarta, 1994

Huwaidi, Fahmi, "al-Islam wa al-Dimuqratiyah", alMustaqbal al-AArabi, no. 166, Desember 1992. 1993

Khalid, Khalid M., Khulafa al-Rasul, Beirut: Dar alKutub al-Ilmiyah, 1974

Krauze, Enrique,"England, the United States, and the Export of Democracy", dalam karya Brad Roberts, ed., The New democraticies: Global Change of US. Policy Cambridge, Mass: MIT Press,1990

Lewis, Bernard, et. al., Islam Liberalisme Demokrasi, Jakarta: Paramadina, 2002

Madjid, Nurcholis, Islam, Doktrin, dan Peradaban, Jakarta: Yayasan Paramadina,1992

Mahfud MD, Moh., Hukum dan Pilar-Pilar Demokrasi, Yogyakarta: Gema Media, 1999

Majid, Ahmad Abdul, Ru'yah Islamiyah Mu'ashirah, Beirut: Dar al-Fikr, 1991
Martin Seymour Lipset, Political Man: The Social Bases of Politics, Doubleday, 1959

Masdar, Umaruddin, dkk., Mengasah Naluri Publik Memahami Nalar Politik, Yogyakarta: LKIS, 1999

Al-Maududi, Al-Hukumah al-Islamiyah, Cairo: alMukhtar al-Islami, 1976

Muller, Edward N., A Dependent Economic Development, Aid Dependence on the United States and Democratic Breakdown in the Third World, International Studies, 1985

al-Nafisy, 'An Ma Yahkum al-Islam, London: TaHa Publisher Ltd., 1980

Othman, M. Fathi, Min Ushul al-Fikr al-Siyasi, Beirut: al-Risalah, 1984

Randall, John Herman, Jr., The Making of The Modern Mind, New York: Columbia University Press, 1976

Robertson, Roland dan Jo Ann Chirico,"Humanity, Globalization, and Worlwide Religious resurgence: A Theoretical Exploration", Sociological Analysis 46, no. 3 tahun 1985

Syadzali, Munawir, Islam and Governmental System, Jakarta: INIS, 1991

Sartori,Giovanni, "Democracy”, dalam karya David L. Sills, ed., International Encyclopedia of Social Science, 1968

Talmon,JL., The Origins of Totalitarian Democracy New York: Frederick A. Praeger, 1960

Vanhanen,Tatu, The Process Democratization; A Comparative Study of 147 States, New York: Crane Russak, 1990

Ubaidillah, A. et. al., Pendidikan Kewargaan Demokrasi, HAM, \& Masyarakat Madani, Jakarta, IAIN Jakarta Press, 2000, Cet. ke-1 